$14^{\text {th }}$ Conf. Agric. Develop. Res., Fac. of Agric., Ain Shams Univ.,

March, 2019, Cairo, Egypt

Special Issue, 27(1), 707 - 715, 2019

Website: http://strategy-plan.asu.edu.eg/AUJASCI/

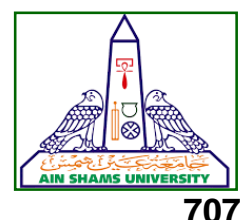

\title{
EFFECT OF SOAKING AND SPROUTING USING SALINE WATER ON CHEMICAL COMPOSITION OF WHEAT GRAINS
}

\author{
Hussein, T.H.A. ${ }^{1}$, Abd El-Shafea ${ }^{1}$ Y.M., El-Behairy ${ }^{2}$ U.A.A. \\ and Abdallah ${ }^{2}$ M.M.F. \\ 1. Regional Center for Food and Feed, Agric. Res. Center. Giza, Egypt \\ 2. Horticulture Dept., Fac. of Agric., Ain Shams Univ., P.O. Box 68, Hadayek Shoubra, 11241, \\ Cairo, Egypt.
}

${ }^{\star}$ Corresponding author: tarekhussein.1968.th@gmail.com

Received 30 December, 2018, $\quad$ Accepted 20 January, 2019

\section{ABSTRACT}

In the current research, wheat grains were used to study the effect of grain soaking and sprouting using tap water and saline water $(\mathrm{NaCl}$ solution) on sprout growth, proximate analysis, minerals content, anti-nutritional and antioxidant compounds of sterilized grains (soaked for $0.33 \mathrm{~h}$ ) and soaked grains for imbibition (12h) and sprouted grain for $24 \mathrm{~h}$ old. Results revealed that the longest radical of $24 \mathrm{~h}$ old wheat sprout was observed at $2000 \mathrm{ppm} \mathrm{NaCl}$, and shortest was observed at $4000 \mathrm{ppm} \mathrm{NaCl}$. Soaked wheat grains (12h) for imbibition recorded the highest moisture content (10.2 to $10.9 \%$ ) while soaked for $20 \mathrm{~min}$ $(0.33 \mathrm{~h})$ in calcium hypochlorite for sterilization recorded medium content (8.8 to $9.9 \%$ ) and the lowest one recorded in $24 \mathrm{~h}$ old wheat sprouts (6.9 to $7.2 \%)$. The low moisture content the high total carbohydrate, total fats and energy and vice versa. Soaked grains for sterilization period $(0.33 \mathrm{~h})$ and imbibition (12h) increased zinc ( $\mathrm{Zn})$, manganese $(\mathrm{Mn})$ and calcium $(\mathrm{Ca})$ while non-sterilized only potassium (K). Tap water increased sprout magnesium $(\mathrm{Mg})$, and manganese $(\mathrm{Mn})$ content while saline water increased sprout magnesium (Mg), and calcium $(\mathrm{Ca})$ content. Grain sprouting was effective in reducing phytic acid, oxalate and alkaloids anti-nutrient in wheat sprouts especially when using sterilized grains. Soaking non sterilized grains for imbibition (12h) in saline water contained higher total phenol, flavonoids and total antioxidant. Etiolated wheat sprouts contained lower total flavonoids and antioxidant compared with soaked grains in saline water.

Key wards: Wheat grains, Soaking, Sprouts, Saline water, proximate analysis, Minerals, Antinutrient, Antioxidant.

\section{INTRODUCTION}

Wheat is one of the first domesticated species to man and is also the first agricultural product used in food processing showing fundamental role in the human food base (Silva et al 2014). The wheat grain has important role in the economic and nutritional aspects of food because their flour is widely used in food industry for the production of flour especially in bread and pasta (Camargo et al 2004). Sprouting grains for human consumption has been used for centuries in Egypt and Asian counties to improve food value (Resh, 2001 and Abdallah, 2008). Therefore, the trend is to produce specially breads and backed goods from whole grain flour and seed sprouts known as functional foods (Dewettinek et al 2008, Jideani and Onwubali, 2009 and Abd allah and Abo El-Naga, 2013). Sprouting is the practice of soaking and leaving seeds until they germinate and begin to sprout. This practice is reported to be associated with improvements in the nutritive value of seeds (Zanabia et al 2006, Abdallah, 2008 and Kumar et al 2010). At the same time there are indications that germination is effective in reducing phytic acid (Kalapadevi and Mohan, 2013 and Ibrahim 2017), and other anti-nutrition of factors (Abd- 
ElAzim et al 2018). Imbibing grains under warm, moist conditions is the only means of determining the germ inability of wheat grains. Water entered the embryo and scutellum during the very early stages of imbibition through the micro pyle and by $2 \mathrm{~h}$ of imbibition, embryo structures such as the coleoptile and radicle were clearly distinguished. Although water accumulated between the inner (seed coat) and outer (pericarp) layers of the coat surrounding the grain, there was no evidence for movement of water directly across the coat and into the underlying starchy endosperm (Rathjen et al 2009).

Salinity is one of the most serious a biotic stress that affects crop production in the arid and similar zone of the world. Seed germination and seedling growth are known to be more sensitive to salt stress compared with later development stages (Ashraf 1994 and Yildirim et al 2002). Salt stress negatively affects plant morphology and physiology through osmotic and ionic stress changes biochemical responses in plant (Khan et al 2013). On The other hand, salt stress stimulates the activity of antioxidant system (Rady. 2011 and Semida and Raoly, 2014).

Germination brought about significant increases in the micronutrient, phytonutrient content of all selected seeds, thus proving that there is marked increase in the nutritive value of the seeds on sprouting. This ultimately signifies that sprouts should be incorporated to improve agricultural productivity and easily to use by low income families (Wagner et al 2013).

The aim of the present study was to investigate the effect of soaking and sprouting using tap water and $\mathrm{NaCl}$ solution for soaked grains and one day sprout characters, proximate analysis, energy, minerals, antioxidants and anti-nutritional compounds of wheat grains

\section{MATERIALS AND METHODS}

This study was carried out in Horticulture Department, Faculty of Agriculture, Ain Shams University and the Regional Center for Food and Feed (RCFF), Agriculture Research center (ARC).

\section{Materials}

\section{1- Wheat grains and $\mathrm{NaCl}$}

Dry wheat grains (Triticumae stivum L.) Cultivar Giza 168 was obtained from Agriculture Research Center, Giza. $\mathrm{NaCl}$ was obtained from ElGomhoria chemical company, Cairo Egypt

\section{2 - Grains sprouting.}

Sprouting of cleaned sterilized by soaking for $20 \mathrm{~min}$ in calcium hypochlorite and non-sterilized whole wheat grain was dame in glass jar method for imbibition soaking (12 h) and others for sprouting as reported by Abdallah, (2008) using tap water and $\mathrm{NaCl}$ at 1000, 2000, 3000, 4000 ppm solution for grain soaking and sprouting, wheat sprout sharvested one day from grain soaking. Grains, soaked grains and harvested sprouts dried using air draft oven at $55 \pm 2^{\circ} \mathrm{C}$ for $48 \mathrm{hr}$. then grounded into powder for chemical analysis. Samples of sprouts were also collected for measuring sprout characters (radical length $(\mathrm{cm}), 100$ sprouts fresh and dry weight $(\mathrm{g})$, weight losses during sprout (\%) and addition to measure imbibed Water $\mathrm{ml} / 100 \mathrm{~g}$ of seeds

\section{3 - Chemical analysis}

Moisture, total protein, lipids, crude fiber and ash contents of the samples were determined according to AOAC (2012). Total carbohydrate determined by subtracting. The energy value was calculated using the at water factor method $[(9 \mathrm{x}$ fat $)+(4 \times$ carbohydrate $)+(4 \times$ protein $)]$ as described by Osborne and Voogl, (1978), Eneche (1991), Chinma, Igyor (2007) and Nwabueze (2007). Potassium (K), magnesium (Mg), iron (Fe), zinc $(\mathrm{Zn})$, calcium $(\mathrm{Ca})$ and manganese $(\mathrm{Mn})$ were analysed by atomic absorption spectrophotometer 3300 perken Elmer, while calcium (Ca) was analyzed by ICP optima 2000 DV perken Elmer. According to the method described in the AOAC (2012). Concerning anti-nutrient analysis, total oxalate was determined through titration methods according to Day and Underwood (1986), phytic acid was determined based on precipitation of phytate according to the procedure of Wheeler and Ferr et al (1971) nitrate calibration curve. Total tannins were determined by spectrophotometric method as described by Makkar et al (1993) and alkaloids determined by procedure proposed by Harbone (1973) and further explained by Onwuka (2006). Saponin content of the samples was determined by double solvent extraction gravimetric method (Harbone 1973 and Obadoni and Ochuko 2001). The total antioxidant capacity of the samples was evaluated by the method of Prieto et al (1999). The Folin Ciocalteu method (Singleton, et al 1999) was used to determine total phenolic content. The total flavonoid content was determined using aluminium chloride colorimetric 

of wheat grains

method as adapted by Arvouet Grand et al (1994).

\section{4- Statistical analysis}

The data were analyzed by analysis of variance using completely randomized design and least significant difference (L.S.D) at 0.05 level according to the method described by Snedecor, Cochran, (1980).

\section{RESULT AND DISCUSSION}

1- Effect of $\mathrm{NaCl}$ concentrations in sprouting solution on grains imbibed water (12h) and one day old wheat grains etiolated sprout characters.

Data in Table (1) showed no statistical significant difference between sterilized and non sterilized grains in wheat sprout radical length, 100 sprout fresh and dry weights and dry weight losses percentage during $24 \mathrm{~h}$ sprouting. But sterilization decreased grain imbibed water. Moreover no sta- tistical difference between tap water and $\mathrm{NaCl}$ concentrations (1000, 2000, 3000 and 4000 ppm) in wheat sprouts fresh and dry weight and percentage of dry weight losses during sprouting. Concerning sprout radical length, the longest radical was observed at $2000 \mathrm{ppm} \mathrm{NaCl}$ with no different with the following observed using tap water , while the shortest radical length was observed at $4000 \mathrm{ppm} \mathrm{NaCl}$ followed by $3000 \mathrm{ppm}$. The higher $\mathrm{NaCl}$ concentration (4000 ppm) increased grain imbibed water compared with control. The interaction between sterilization and $\mathrm{NaCl}$ concentration recorded the tallest radical length in $2000 \mathrm{ppm}$ $\mathrm{NaCl}$ followed by tap water with or without grain sterilization. The higher imbibed water was recorded with all $\mathrm{NaCl}$ concentration interacts with nonsterilized seeds. Therefore 2000 ppm $\mathrm{NaCl}$ was selected for the following study. Similar results on decreasing sprout length with increasing $\mathrm{NaCl}$ concentration were reported by Ibrahim (2017), Abd El- Azim et al (2018) and Basma Soliman et al (2018).

Table 1. Effect of $\mathrm{NaCl}$ concentrations in sprouting solution on grains imbibed water $12 \mathrm{~h}$ and one day old wheat grains etiolated sprout characters

\begin{tabular}{|c|c|c|c|c|c|c|}
\hline $\begin{array}{l}\text { Sterilization } \\
\text { (ST ) }\end{array}$ & $\begin{array}{c}\mathrm{Na} \mathrm{Cl} \\
\text { Concentration } \\
\text { PPM }\end{array}$ & $\begin{array}{l}\text { Radical } \\
\text { length } \\
(\mathrm{cm})\end{array}$ & $\begin{array}{l}100 \text { Sprout } \\
\text { fresh Weight } \\
\text { (g) }\end{array}$ & $\begin{array}{c}100 \text { Sprout } \\
\text { dry weight }(\mathrm{g})\end{array}$ & $\begin{array}{c}\text { weight Losses } \\
\text { during sprout } \\
\text { (\%) }\end{array}$ & $\begin{array}{c}\text { Imbibed water } \\
\mathrm{ml} / 100 \mathrm{~g} \\
\text { seeds }\end{array}$ \\
\hline \multirow{6}{*}{ 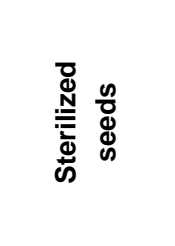 } & Tap Water & $0.244 \mathrm{a}$ & $7.286 \mathrm{a}$ & $4.53 \mathrm{a}$ & $6.54 \mathrm{a}$ & $61.95 \mathrm{~d}$ \\
\hline & 1000 & $0.175 \mathrm{bcd}$ & $7.008 \mathrm{a}$ & $4.412 \mathrm{a}$ & $6.40 \mathrm{a}$ & $66.68 \mathrm{~cd}$ \\
\hline & 2000 & $0.250 \mathrm{a}$ & $6.939 a$ & $4.342 \mathrm{a}$ & $5.19 a$ & 72.44 bc \\
\hline & 3000 & $0.149 \mathrm{bc}$ & $6.817 \mathrm{a}$ & $4.287 \mathrm{a}$ & $5.01 \mathrm{a}$ & $65.70 \mathrm{~cd}$ \\
\hline & 4000 & $0.115 d$ & $6.855 \mathrm{a}$ & $4.361 \mathrm{a}$ & $6.31 \mathrm{a}$ & $75.43 \mathrm{abc}$ \\
\hline & Mean & $0.187 \mathrm{~A}$ & $6.981 \mathrm{~A}$ & $4.386 \mathrm{~A}$ & $5.89 \mathrm{~A}$ & 68.44 B \\
\hline \multirow{6}{*}{ 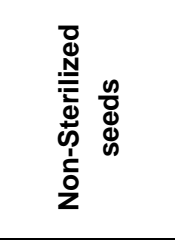 } & Tap Water & $0.238 a b$ & $7.183 \mathrm{a}$ & $4.389 \mathrm{a}$ & $4.94 \mathrm{a}$ & $78.64 \mathrm{ab}$ \\
\hline & 1000 & $0.189 a b c$ & $6.947 \mathrm{a}$ & $4.337 \mathrm{a}$ & $4.94 \mathrm{a}$ & $79.85 \mathrm{a}$ \\
\hline & 2000 & $0.252 \mathrm{a}$ & $6.988 \mathrm{a}$ & $4.475 \mathrm{a}$ & $5.46 \mathrm{a}$ & $73.84 \mathrm{abc}$ \\
\hline & 3000 & $0.149 \mathrm{~cd}$ & $7.247 \mathrm{a}$ & $4.394 \mathrm{a}$ & $5.92 \mathrm{a}$ & $72.70 \mathrm{abc}$ \\
\hline & 4000 & $0.143 \mathrm{~cd}$ & $7.102 \mathrm{a}$ & $4.564 \mathrm{a}$ & $6.68 \mathrm{a}$ & $82.98 \mathrm{a}$ \\
\hline & Mean & $0.194 \mathrm{~A}$ & $7.093 \mathrm{~A}$ & $4.432 \mathrm{~A}$ & $5.59 \mathrm{~A}$ & $77.60 \mathrm{~A}$ \\
\hline \multirow{5}{*}{$\begin{array}{l}\stackrel{0}{0} \\
\frac{\pi}{0} \\
\stackrel{0}{⿺}\end{array}$} & Tap Water & $0.241 \mathrm{~A}$ & $7.235 \mathrm{~A}$ & $4.459 \mathrm{~A}$ & $5.74 \mathrm{~A}$ & $70.30 \mathrm{~B}$ \\
\hline & 1000 & 0.182 B & $6.977 \mathrm{~A}$ & $4.374 \mathrm{~A}$ & $5.67 \mathrm{~A}$ & $73.26 \mathrm{AB}$ \\
\hline & 2000 & $0.251 \mathrm{~A}$ & $6.963 \mathrm{~A}$ & 4. $408 \mathrm{~A}$ & $5.33 \mathrm{~A}$ & $73.14 \mathrm{AB}$ \\
\hline & 3000 & $0.149 \mathrm{BC}$ & $7.032 \mathrm{~A}$ & $4.341 \mathrm{~A}$ & $5.46 \mathrm{~A}$ & $69.20 \mathrm{~B}$ \\
\hline & 4000 & $0.129 \mathrm{C}$ & $6.979 \mathrm{~A}$ & $4.462 \mathrm{~A}$ & $6.49 \mathrm{~A}$ & $79.21 \mathrm{~A}$ \\
\hline \multirow{3}{*}{ LSD 0.05} & (ST) & NS & NS & $N S^{(1)}$ & NS & 4.629 \\
\hline & $\mathrm{NaCl}$ & 0.047 & NS & NS & NS & 7.32 \\
\hline & $\mathrm{ST} \times \mathrm{NaCl}$ & 0.066 & NS & NS & NS & 10.352 \\
\hline
\end{tabular}

Means in each column followed by the same letter are not significantly different at the $p<0.05$ 
2- Proximate analysis and energy content of wheat grain soaked for $0.33 \mathrm{~h}$ (sterilized period), soaked $12 \mathrm{~h}$ (imbibition period) and $24 \mathrm{~h}$ sprouts.

Soaked wheat grains $12 \mathrm{~h}$ for imbibitions recorded the higher moisture content in dry samples $(10.2$ to $10.9 \%)$ with and without grain sterilization and saline water ( $\mathrm{NaCl} 2000 \mathrm{ppm}$ ) while soaked grains for $0.33 \mathrm{~h}$ in calcium hypochlorite $2 \%$ for grain sterilization recorded medium moisture content $(8.8$ to $9.9 \%)$. But moisture content of wheat sprouts $24 \mathrm{~h}$ old was the lowest with and without sterilization and saline water (6.9 to $7.2 \%)$ as shown in Table (2). The lower moisture content in wheat sprouts showed increase in total carbohydrates $(74.55$ to $74.89 \%)$, and total fats $(2.01$ to $2.07 \%$ ) compared with other treatment. On the other hand the higher moisture content in soaked grains for imbibitions $12 \mathrm{~h}$ showed decreased in carbohydrate (71.41 to $72.25 \%$ ), fat (1.99 to $2.0 \%$ ) and fiber (1.78 to $1.98 \%$ ) compared with other treatments. Concerning protein and ash data showed close content between treatments for both. (Table 2). Regarding energy, the higher energy value (367.9 to 368.9 ) recorded in the lowest moisture content and higher carbohydrates and fat. Similar results were obtained by Abd El- Azim et al (2018) and Basma Soliman et al (2018). The higher energy value can discuss by increasing carbohydrates and fats with no clear changes in protein.

Since the energy value was calculated using the at water factor method $(9 \times$ fat $)+(4 \times$ carbohydrate $)+(4 \times$ protein $)$.

Table 2. The proximate analysis $\mathrm{g} / 100 \mathrm{gdw}$ and energy content of wheat grain soaked for $0.33 \mathrm{~h}$ (sterilized period), soaked $12 \mathrm{~h}$ (imbibition period) and $24 \mathrm{~h}$ sprouts.

\begin{tabular}{|l|c|c|c|c|c|c|c|}
\hline \multicolumn{1}{|c|}{ Treatment } & Moisture & Carbohydrate & Protein & Fat & Fiber & Ash & $\begin{array}{c}\text { Energy } \\
(\text { Kcal/g) }\end{array}$ \\
\hline sterilized grains -TW ${ }^{(1)}$ - ST ${ }^{(2)}(0.33 \mathrm{hr})$ & 8.8 & 73.44 & 12.4 & 1.92 & 1.94 & 1.5 & 360.6 \\
non-sterilized grains -TW - NST $^{(3)}(0.33 \mathrm{hr})$ & 9.9 & 71.45 & 13.3 & 1.95 & 2.00 & 1.4 & 356.6 \\
soaked grains (12hr) - -TW- ST & 10.9 & 71.73 & 12.2 & 1.99 & 1.78 & 1.4 & 353.6 \\
soaked grains (12hr) - TW - NST & 10.2 & 72.25 & 12.3 & 2.00 & 1.85 & 1.4 & 356.7 \\
soaked grains (12hr ) -SW ${ }^{(4)}$ - ST & 10.7 & 71.41 & 12.7 & 2.00 & 1.79 & 1.4 & 354.4 \\
soaked grains (12hr ) -SW - NST & 10.5 & 72.13 & 12.1 & 1.99 & 1.98 & 1.3 & 354.8 \\
sprout- TW - ST & 7.0 & 74.55 & 13.1 & 2.02 & 1.93 & 1.4 & 368.9 \\
sprout- TW - NST & 7.2 & 74.55 & 12.8 & 2.05 & 2.00 & 1.4 & 367.9 \\
sprout SW - ST & 6.9 & 74.89 & 12.6 & 2.01 & 2.10 & 1.5 & 368.1 \\
sprout SW -NST & 7.1 & 74.82 & 12.5 & 2.07 & 2.11 & 1.5 & 367.9 \\
\hline
\end{tabular}

(1)TW=tap water (2) ST=sterilized seeds (3) NST=non-sterilized seeds (4) SW=saline water (NaCl 2000 ppm)

\section{3- Minerals content of wheat grain soaked for $0.33 \mathrm{~h}$ (sterilized period), soaked $12 \mathrm{~h}$ (imbibi- tion period) and $24 \mathrm{~h}$ sprouts.}

Concerning effects of sprouting using saline water with sterilized and non-sterilized grains on mineral contents, data in Table (3) showed that sterilized dry grains for $0.33 \mathrm{~h}$ in calcium hypochlorite $2 \%$ increased $\mathrm{Zn}, \mathrm{Mn}$ and $\mathrm{Ca}$ while nonsterilized dry grains increased only $\mathrm{K}$ compared with other minerals. Moreover, sterilized grains soaked for $12 \mathrm{~h}$ in tap water for imbibition increased grains $\mathrm{Fe}, \mathrm{Zn}, \mathrm{Mn}$ and $\mathrm{Ca}$ contents white nonsterilized grains soaked for $12 \mathrm{~h}$ in tap water increased grains $\mathrm{K}$ content only compared with other minerals, also Fe content was increased in sterilized grains soaked for $12 \mathrm{~h}$ in saline water. On the other hand wheat grains sprout contain higher $\mathrm{Mg}$ and $\mathrm{Mn}$ using sterilized and non-sterilized grains sprouting in tap water, but using saline water decreased sprout Mg content and increased Ca content compared with other sprout.

\section{4- Anti-nutrient compounds of wheat grain soaked for $0.33 \mathrm{~h}$ (sterilized period), soaked $12 \mathrm{~h}$ (imbibition period) and $24 \mathrm{~h}$ sprouts}

The anti-nutrient compositions are presented in Table (4). Tannins were increased in non-sterilized dry wheat grains soaked for 20 minutes $0.33 \mathrm{~h}$ and also increased in grains sprouts specialty when using tap water for sterilized and non-sterilized grains sprouting. 
Table 3. Minerals content (ppm) of wheat grain soaked for $0.33 \mathrm{~h}$ (sterilized period), soaked $12 \mathrm{~h}$ (imbibition period) and $24 \mathrm{~h}$ sprouts.

\begin{tabular}{|c|c|c|c|c|c|c|}
\hline Minerals & $\mathbf{K}$ & Mg & $\mathrm{Fe}$ & Zn & Mn & $\mathrm{Ca}$ \\
\hline sterilized grains $-\mathrm{TW}^{(1)}-\mathrm{ST}^{(2)}(0.33 \mathrm{hr})$ & 700 & 48.92 & 0.5904 & 0.3452 & 0.1303 & 532 \\
\hline non-sterilized grains $-\mathrm{TW}-\mathrm{NST}^{(3)}(0.33 \mathrm{hr})$ & 1500 & 67.98 & 0.6160 & 0.0713 & 0.0293 & 405 \\
\hline soaked grains (12hr) -TW-ST & 500 & 57.76 & 0.8929 & 0.348 & 0.1326 & 516 \\
\hline soaked grains (12hr) - TW - NST & 1000 & 57.48 & 0.253 & 0.2220 & 0.0094 & 413 \\
\hline soaked grains (12hr) $-S W^{(4)}-\mathrm{ST}$ & 400 & 71.30 & 0.7555 & 0.084 & 0.0998 & 414 \\
\hline soaked grains (12hr ) -SW - NST & 500 & 64.04 & 0.5020 & 0.2173 & 0.1357 & 289 \\
\hline sprout- TW - ST & 500 & 73.04 & 0.7387 & 0.1743 & 0.1813 & 386 \\
\hline sprout- TW - NST & 400 & 72.94 & 0.1058 & 0.249 & 0.1278 & 376 \\
\hline Sprout SW - ST & 500 & 53.58 & 0.7536 & 0.1013 & 0.0383 & 489 \\
\hline sprout SW - NST & 500 & 52.58 & 0.6317 & 0.1159 & 0.0563 & 491 \\
\hline
\end{tabular}

(1)TW=tap water (2) ST=sterilized seeds (3) NST=non-sterilized seeds (4) SW=saline water ( $\mathrm{NaCl} 2000 \mathrm{ppm}$ )

Table 4. Anti-nutrient compounds of wheat grain soaked for $0.33 \mathrm{~h}$ (sterilized period), soaked $12 \mathrm{~h}$ (imbibition period) and $24 \mathrm{~h}$ sprouts.

\begin{tabular}{|cccccc|}
\hline $\begin{array}{c}\text { Anti-nutritional } \\
\text { compounds }\end{array}$ & $\begin{array}{c}\text { Tannins } \\
\%\end{array}$ & $\begin{array}{c}\text { PhyticAcid } \\
\%\end{array}$ & $\begin{array}{c}\text { Oxalate } \\
\%\end{array}$ & $\begin{array}{c}\text { Alkaloids } \\
\%\end{array}$ & $\begin{array}{c}\text { Saponins } \\
\%\end{array}$ \\
\hline $\begin{array}{c}\text { sterilized grains -TW } \\
\text { (1) }-\mathrm{ST}^{(2)}(0.33 \mathrm{hr})\end{array}$ & 0.09 & 0.57 & 0.05 & 4.72 & 0.53 \\
non-sterilized grains -TW - NST ${ }^{(3)}$ & 0.16 & 0.48 & 0.076 & 8.59 & 1.56 \\
(0.33hr) & & & & & \\
soaked grains (12hr ) -TW- ST & 0.15 & 0.67 & 1.20 & 4.77 & 2.69 \\
soaked grains (12hr ) - TW - N ST & 0.14 & 0.62 & 1.12 & 3.20 & 1.70 \\
soaked grains (12hr ) -SW ${ }^{(4)}$ - ST & 0.16 & 0.68 & 1.20 & 4.35 & 2.34 \\
soaked grains (12hr ) -SW - NST & 0.14 & 0.69 & 1.10 & 3.20 & 1.90 \\
sprout- TW - ST & 0.17 & 0.58 & 0.95 & 1.95 & 0.67 \\
sprout- TW - N ST & 0.16 & 0.60 & 1.20 & 4.60 & 2.40 \\
Sprout SW - ST & 0.15 & 0.58 & 1.00 & 2.52 & 1.48 \\
Sprout SW -N ST & 0.14 & 0.59 & 1.10 & 3.18 & 1.93 \\
\hline
\end{tabular}

(1)= tap water (2) ST=sterilized seeds (3) NST=non-sterilized seeds (4) SW=saline water ( $\mathrm{NaCl} 2000 \mathrm{ppm})$

The phytic acid and oxalate percentage were increased in soaking grains for imbibition's $12 \mathrm{~h}$ while decreased in all sprouts treatments and in dry grains soaked for $0.33 \mathrm{~h}$ during sterilization. However, Kalpanadevi and Mohan (2013) reported that germination is effective in reducing phytic acid. Alkaloids showed highest content (8.59\%) in non-sterilized dry grains soaked for $0.33 \mathrm{~h}$ in tap water, followed by sterilized dry grains, sterilized soaked grains $12 \mathrm{~h}$ and non-sterilized grains sprouts using tap or saline water. Concerning saponins data showed elevation of saponin percentage in non-sterilized dry grains soaked for $0.33 \mathrm{~h}$ in tap water, and sterilized grain soaking $12 \mathrm{~h}$ for imbibition, and non-sterilized grain sprout, in both tap and saline water the saponin used as precursor for the synthesis of steroid hormones. Also saponine especially diosgnin also exhibited anticancer, anti-diabetes, anti-microbial properties and anti-aging activities (Tada et al 2009, Yan et al 2009 and Chaudhary et al 2018). However scientific studies have established that germination improve the nutritional quality of food products by reducing or eliminating the anti-nutrient composition of food products (Mbithi- Mwikya et al 2001, Ibrahim 2017, and Abd El- Azim et al 2018). 
5- Antioxidant compound of wheat grain soaked for $0.33 \mathrm{~h}$ (sterilized period), soaked 12h (imbibition period) and $24 \mathrm{~h}$ sprouts.

Table (5) showed the effect of wheat sterilized grains for $0.33 \mathrm{~h}$ soaked grains for $12 \mathrm{~h}$ and etiolated sprout $24 \mathrm{~h}$ old on total phenols, total flavonoids and total antioxidant content (ppm). Non sterilized grain soaked for $12 \mathrm{~h}$ in saline water contained higher total phenols (2425 ppm), flavonoids (314 ppm) and total antioxidant (6337 ppm), than other treatments. However saline water increased total antioxidant in soaked grains for $12 \mathrm{~h}$. In contrast grains etiolated sprout in saline water for $24 \mathrm{~h}$ contained lower total flavonoids, and antioxidant compared with soaked grains. The high increases in total phenol and flavonoids in $12 \mathrm{~h}$ soaked grains may be due to that soaking processes synthesized these compounds with vitamin $\mathrm{C}$ as good antioxidant agents against salinity.

Table 5. Antioxidant compound (ppm) of wheat grain soaked for $0.33 \mathrm{~h}$ (sterilized period), soaked $12 \mathrm{~h}$ (imbibition period) and $24 \mathrm{~h}$ sprouts.

\begin{tabular}{|c|c|c|c|}
\hline Compounds & \begin{tabular}{|c} 
Total \\
Phenols \\
ppm
\end{tabular} & \begin{tabular}{|c} 
Total \\
Flavonoids \\
ppm
\end{tabular} & $\begin{array}{c}\text { Total } \\
\text { Antioxidant } \\
\text { Ppm }\end{array}$ \\
\hline $\begin{array}{l}\text { sterilized grains- }-\mathrm{TW}^{(1)}-\mathrm{ST}^{(2)} \\
(0.33 \mathrm{hr})\end{array}$ & 1304.5 & 250.6 & 4813 \\
\hline $\begin{array}{ll}\text { non-sterilized } & \text { grains-TW- } \\
\mathrm{NST}^{(3)}(0.33 \mathrm{hr}) & \end{array}$ & 844 & 250.6 & 3728 \\
\hline soaked grains (12hr)-TW- ST & 1105 & 240.6 & 4079 \\
\hline $\begin{array}{l}\text { soaked grains (12hr)- TW- } \\
\text { NST }\end{array}$ & 2156 & 240.6 & 5510 \\
\hline $\begin{array}{l}\text { soaked grains }(12 \mathrm{hr})-\mathrm{SW}^{(4)} \text { - } \\
\text { ST }\end{array}$ & 1716 & 250.4 & 5996 \\
\hline $\begin{array}{l}\text { soaked grains (12hr)- SW - } \\
\text { NST }\end{array}$ & 2425 & 314.2 & 6337 \\
\hline sprout- TW - ST & 2171 & 84.9 & 4313 \\
\hline sprout- TW - N ST & 1943 & 112.1 & 4484 \\
\hline sprout SW - ST & 1151 & 71.6 & 3830 \\
\hline sprout SW -N ST & 1242 & 82.6 & 4014 \\
\hline
\end{tabular}

$\mathrm{TW}=$ tap water (2) ST=sterilized seeds (3) NST=non-sterilized seeds (4) $\mathrm{SW}=$ saline water $(\mathrm{NaCl} 2000 \mathrm{ppm})$

\section{REFERENCES}

Abdallah, M.M.F. 2008. Seed sprouts, a pharaoh's heritage to improve food quality. Arab Univ. J. Agric. Sci., 16(2), 469-478.

Abdallah, M.M.F. and Abo El-Naga M. 2013. Use of seed sprouts flour to improve cake quality. J. Biol. Chem. and Environ. Sci.. 8(1), 279-298.

Abd El-Azim, M.A., Nashwa A.I. Abo El-Azam, Afaf O. Serage and Abdallah M.M.F. 2018. Sprouting using saline water on chemical composition, anti-nutritional compounds and amino acid profile of chickpea and lentil seeds. Arab Univ. J. Agric. Sci., Ain Shams Univ., Cairo, Egypt Special Issue, 26(2), in Press.

AOAC. 2012. Official Methods of Analysis of AOAC International. $19^{\text {th }}$ Ed. Dumes Method. No. 968.06, Chapter 4, pp. 25-26.

Arvouet-Grand, A., Vennat, B., Pourrat, A., Legret P., 1994. Standardization dun extrait de propolis et identification des principaux constituents. Journal de Pharmacie de Beigique 49, 642-468.

Ashraf, M. 1994. Breeding for salinity tolerance in plants. Critical Reviews in Plant Science. 13 (1), 17-42.

Basma M.M. Soliman, Nashwa A.I. Abu-El Azm, M.H. Elgammal and M.M.F. Abdallah 2018. Effect of sprouting using sajine water on storage wheat grain sprouts character, proximate analysis and phytochemical compounds fraction. Arab Univ. J. Agric. Sci., Ain Shams Univ., Cairo, Egypt Special Issue. 26(2), in Press.

Camargo, C.E.O., Ferreira-Filho A.W.P. and SaIomon M.V. 2004. Temperature and PH of the nutrient solution on wheat primary root growth. Sci. Agric., Piracicaba 61 (3), 313-318.

Chaudhary, P.S.C., Mahesh S.K.C. and Miriti. C.S, 2018. Review on Fenugreek (Trigonella foenum-graecum L.) and its Important Secondary Metabolite Diosgenin. Not Bot Agrobo, 46(1), 22-31.

Chinma, C.E. and Igyor M.A. 2007. Micronutrients and anti-nutritional contents of selected tropical vegetable grown in South East. Nigeria. Nig. Food J. 25, 111-116.

Day, R.A. and Underwood, A.L. 1986. Quantitative Analysis (5 ${ }^{\text {th }}$ Ed.), Prentice-Hall Publication. $701 \mathrm{P}$.

Dewettinck, K.; F. V; B. Kuhne; Van de Walle; T. Courtens and X. Gellynck 2008. Nutritional value of bread influence of processing food in- 
teraction and consumer perception. Rev. J. Cereals Sci., 48, 243-257.

Eneche, E. H. 1991. Biscuit-making potential of millet/pigeon pea flour blends. Plants Foods Human Nutr. 54, 21 - 27.

Harbone, J.B. 1973. Phytochemical Methods. A guide to Modern Techniques of Plant Analysis, Chapman and Hall: New York, USA, 278p.

Ibrahim. E.M.R, 2017. Effect of Sprouting Using saline Water on Characters and Chemical Composition of some Legumes and Cereals Seeds. Ph.D. Thesis. Fac. Agric. Ain Shams Univ. Cairo. Egypt. pp. 32-80.

Jideani, V. and Onwubali F. 2009. Optimization of wheat sprouted soya bean flour bread using response surface methodology. Afr. J. Biotechnology. 8(22), 6364-6373.

Kalpanadevi, V. and Mohan V.R. 2013. Effect of processing on ant nutrients and in vitro protein digestibility of the underutilized legume, Vigna Unguiculata L. Walp subsp. Unguiculata. LWTFood Sci. Technol. 51, 455-461.

Khan M.I.R., Mughal A., Iqpal N. and Khan A., 2013. Potentiality of sulphur containing com-pounds in salt stress tolerance. In Ecophysiolgy and responses of plants under salt stress Eds. Parvaiz, A.M.M. Azooz and M.N.V. Prasad, springer, pp. 443-473.

Kumar, V., Sinha A.K., Makkar H.P.S. and Becker K. 2010. Dietary roles of phytate and phytase in human nutrition. Review. Food Chemistry. 120, 945-959.

Makkar, H.P.S., BluSmmel, M., Borowy, N.K. and Becker, K. 1993. Gravimetric determination of tannins and their correlations with chemical and protein precipitation methods. J. of the Sci., Food and Agriculture 61,161-165.

Mbithi-Mwikya S., Van Camp J., RodriGuaz R. and Huyghebaert A. 2001. Effects of sprouting on nutrient and antinutrient composition of kidney beans. Eur. Food Res. Technol., 212, 188-191.

Nwabueze, T.U. 2007. Nitrogen solubility index and amino acid profile of extruded African breadfruit ( $T$. Africana) blends. Nig. Food J. $25,35-36$.

Obadoni, B.O. and Ochuko, P.O., 2001. Phytochemical Studies and Comparative Efficacy of the Crude Extracts of Some Homeostatic Plants in Edo and Delta States of Nigeria. Global J. Pure Appl. Sci., 8, 203-208.

Onwuka, G.I., 2006. Soaking, boiling and antinutritional factors in Pigeon Pea (Cajanusca- jan) and Cowpea (Vignaunguiculata). J. Food Processing and Preservation, 30,616-630.

Osborne, D.R. and Voogt, P. 1978. In: calculation of caloric value in the analysis of nutrients in foods. Academic Press, New York, USA, pp. 239-240.

Prieto, P., Pineda, M. and Aguilar, M., 1999. Spectrophotometric quantitation of antioxidant capacity through the formation of phosphor mobdenum complex: specific application to the determination of vitamin E. Analytical Biochemistry, 269(2), 337-341.

Rady M.M. 2011. Effect of 24-epibrassinoillde on growth, yield. Antioxidant system and cadmium content of bean (Phaseolus vulgaris L.). Plant under Salinity and cadmium stress. Scientia Horticulturae, 129, 232-237.

Rathjen Judith R. Rathjen, E.V.S. and D.J.M 2009. Water movement into dormant and nondormant wheat (Triticumae stivum L.) grains $\mathbf{J}$. Experimental Botany, 60(6), 1619-1631.

Resh, H.M. 2001. Hydroponic Food Production, $6^{\text {th }}$ Ed., 567 p. Woodbridge Press, Santa Barbara, CA, USA.

Semida W.M. and Rady M.M. 2014. Presoaking application of propolisand maize grain extracts alleviates salinity stress common bean (Pharsalus vulganis L.). Science Horticulture, 168, 201-217.

Silva, S.Z.D., Rosa T.C.M.D., Tessaro D. and Coeiho S.R.M. 2014. Technological quality of non- germinated whole wheat flour. J. Food Agric. and Environmental 12(2), 132-134.

Singleton, V.L., Orthofer, R., LamuelaRaventos, R.M. 1999. Analysis of total phenols and other oxidation substrates and antioxidants by means of Folin- Ciocalteureagent. Methods Enzymol. 299, 152-178.

Snedecor, G. W. and W.G. Cochran 1980. Statistical methods $7^{\text {th }}$ Ed., lowa State Univ. Press, Ames lowa, USA.

Tada Y., Kanda N., Haratake A. Tobiishi M., Uchiwa H.M. Watanabe S. 2009. Novel effects of diosgenin on skin aging Steroids 74(6), 504-511.

Wagner, A.E., Terschluesen, A.M., Rimbach, G., 2013. Health promoting effects of Brassica derived phytochemicals from chemopreventive and anti-inflammatory activities to epigenetic regulation. Oxid. Med. Cell Longev, 12p.

Wheeler, E.L. and R.E. Ferrel1971. A method for phytic acid determination in wheat and wheat fractions. Cereal Chemistry. 48, 312-320. 
Yan L.L., Zhang Y.J.M., Gao W.Y., Man S.L., Wang Y. 2009. In vitro and in vivo anticancer activity of steroid saponins of Paris polyphyllavar. yunnanensis. Experimental Oncology 31(1), 27-32.

Yildirim, E., Dursun A., Guvenc I. and Kumlay A., 2002. The effects of different salt, bio stimu lant and temperature levels on seed germination of some vegetable species. Acta Agrobotanica. 55, 75-80.

Zanabria, E.R., Katarzyna N., De Jong L.E.Q., Birgit H.B.E. and Robert M.J.N. 2006. Effect of food processing of pearl millet (Pennisetum glaucum) IKMP-5 on the level of phenolics, phytate, iron and zinc. J. Sci. Food Agric. 86, 1391-1398. 
تاثير النقع والتنبيث باستخدام الماء المملح على المكونات الكيميائيه

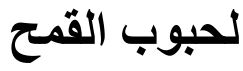

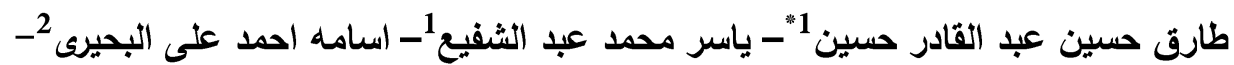

$$
\begin{aligned}
& \text { ممدوح محمد فوزى عبد الله } 2
\end{aligned}
$$

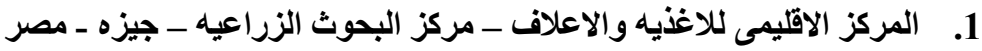

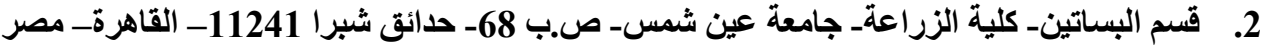

$$
\begin{aligned}
& \text { "Corresponding author: tarekhussein.1968.th@gmail.com }
\end{aligned}
$$

Received 30 December, 2018,

Accepted 20 January, 2019

أنه كلما انخفضت رطوبه العينات كلما زاد محتواها من الكربوهيدرات والدهون والطاقه و العكس صحيح، هذا لإنا

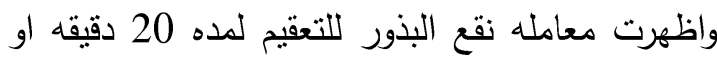
النقع للنترب لمده 12 ساعه زياده فى محتوى عينات تللك الحبوب من عناصر الزنأك والمنجنيز والكالسيوم، فيادئ بينما ازداد البوتاسيوم فقط فى عينات النقع لمده 20

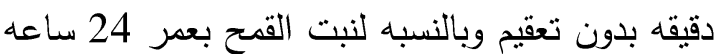

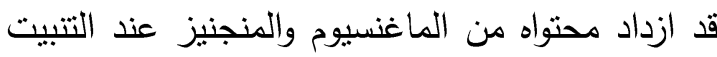
بإستخدام ماء الصنبور ، بينما زاد الماغنسيوم والكالسيوم المانيز

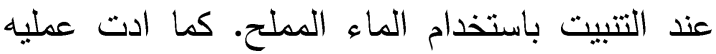
التتبيت الكفاءه في تقليل محتوى النبت من المضادات كيات التيات التيات التغذويه منل حمض الفايتك والاوكسالات والقلويدات خاصه عند استخدام الحبوب المعقمه بهييوكلوريت الكالسيوم هذا وادى نقع حبوب القمح غير المعقمه لكده المئ

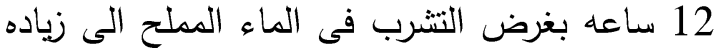
محتواها من الفينولات والفلافنويدات ومضادات الفات الاكسده

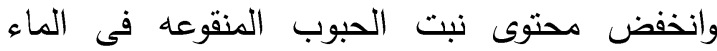
المملح من الفلافونيدات ومضادات الأكسدة.

الكلمات الداله: حبوب القصح، النقع، النبت، الماء المالح، تحليل المكونات، العناصر الغذائيه، مضادات

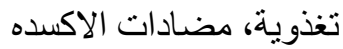

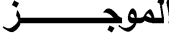

تم فى هذا البحث استخدام حبوب القمح لدراسه تاثير نقع الحبوب والتنبيت باستخدام الماء المدلح بكلوريد الصوديوم مقارنه بماء الصنبور العادى على بلى الثلى

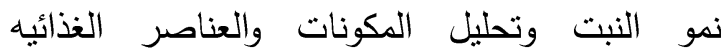
ومضادات التغذيه ومضادات الاكسده للحبوب المعقمة

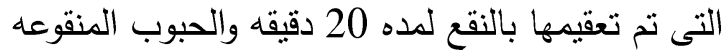
12 ساعه لاجراء عمليه النترب بالمياه وكذلك نبت

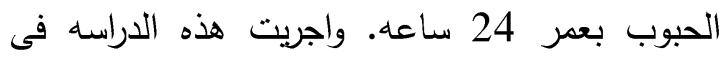
معمل الزراعه العضويه والخضروات النابته بقسم

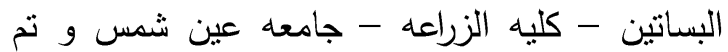
تقدير التحليلات الكيميائيه بالمركز الاقليمى للاغذيه تائيه

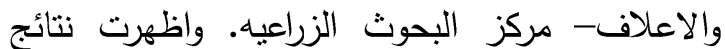

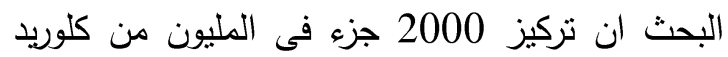

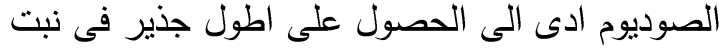

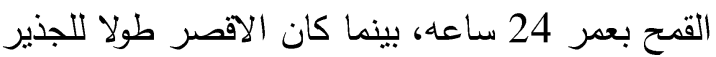

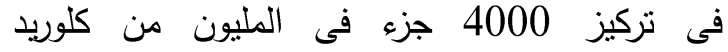
الصوديوم وسجلت عمليه نقع الحبوب لمده 12 ساعه بغرض التشرب اعلى محتوى من الرطوبه وصلت الى وسلى 10.2- 10.9\%، بينما اظهرت الحبوب المنقوعه لمده 20 دقيقه للتعقيم فى هيبوكلوريد الكالسيوم محتوى متوسط من الرطوبه 6.9 - 7.2 \%، واظهرت النتائج 